[Radiocarbon, Vol. 16, No. 3, 1974, P. 388-394]

\title{
TALLINN RADIOCARBON DATES II
}

\author{
J M PUNNING, T KAKUM, and R RAJAMÄE \\ Institute of Geology, Academy of Sciences, Estonian SSR
}

The following list includes samples dated in 1973. Benzene is used as the carrier of natural ${ }^{14} \mathrm{C}$ activity as previously described (Punning et al, 1973). We used both 1-channel and 2-channel scintillation devices. The detector shield comprises $10 \mathrm{~cm}$ lead. Around the detector we put 16 Geiger-Mueller type counters in anticoincidence circuit with output signals from detector. It decreased the average background ca 20 to $40 \%$.

Calculations are based on a ${ }^{14} \mathrm{C}$ half-life of $5568 \pm 30 \mathrm{yr}$. All dates are reported in years before 1950 .

\section{Alasoo series}

Alasoo peat bog is on the $\mathrm{W}$ beach of Lake Peipsi, Tartu Dist, Estonian SSR. Organic deposits (reed peat and sapropel) are buried under beach barrier. Samples are from vertical gutter-wall of prospecting shaft to $250 \mathrm{~cm}$ and from borehole at greater depths. Coll 1971 and subm by U Paap and R Pirrus, Inst Geol, Acad Sci Estonian SSR (now Inst Geol). Comment: pollen analyses by $\mathrm{R}$ Pirrus.

Tln-39. Alasoo

$1270 \pm 50$

Reed peat at depth 114 to $117 \mathrm{~cm}$. Pollen Zone SA 2.

TIn-61. Alasoo

$2770 \pm 50$

820 BC and $\mathrm{SA}_{2}$.

Reed peat at depth 141 to $144 \mathrm{~cm}$. Boundary of Pollen Zones $\mathrm{SA}_{1}$

\section{Tln-47. Alasoo}

$5935 \pm 45$

Reed peat at depth 220 to $225 \mathrm{~cm}$. Pollen Zone SB21.

TIn-43. Alasoo

Sapropel at depth 350 to $360 \mathrm{~cm}$. Pollen Zone BO2.

TIn-32. Alasoo

$8340 \pm 70$

Sapropel at depth 380 to $390 \mathrm{~cm}$. Pollen Zone BOl.

Tln-45. Kuressaare

Relic from SE excavations of Kuressaare Castle, Kingissepa Dist, I Saaremaa, Estonian SSR. Coll 1972 and subm by J Selirand, Inst Hist, Acad Sci, Estonian SSR. Comment: samples from excavations of Kuressaare Castle were dated earlier (Tln-5, -6, -37, -38: R, 1973, v 15, p 586$591)$. 
Bolshaya Lagorta series

\section{Tln-42. Bolshaya Lagorta}

$$
1760 \pm 60
$$

AD 190

Peat from ancient lake sediments of the upstream Bolshaya Lagorta R. Two layers of organic sediments are in profile at depth to $145 \mathrm{~cm}$ and 450 to $485 \mathrm{~cm}$. Loam with wood remains separates the peat layers. Coll 1972 at depth 27 to $35 \mathrm{~cm}$ and subm by L Troitski, Inst Geog Acad Sci USSR (now Inst Geog).

\section{Tln-55. Bolshaya Lagorta}

$3300 \pm 110$

Peat from depth 60 to $68 \mathrm{~cm}$.

\section{Tln-41. Bolshaya Lagorta} 1350 вC

Peat from depth 140 to $145 \mathrm{~cm}$.

Tln-54. Bolshaya Lagorta

$4385 \pm 60$

2435 BC

Peat from depth $470 \mathrm{~cm}$.

$4540 \pm 60$

2590 BC

Tln-40. Bolshaya Lagorta

$7790 \pm 80$

5840 BC

Remains of wood from depth $650 \mathrm{~cm}$.

$8355 \pm 90$

Tln-44. Sveagruve

6405 BC

Shells from sandy clays from a terrace, $7 \mathrm{~m}$ high, on W Spitzbergen, near Sveagruve. Coll 1967 and subm by L Troitski.

\section{Tln-46. Usher}

$8025 \pm 95$

$6075 \mathrm{BC}$

Peat from a terrace at height $22 \mathrm{~m}$ in outwash deposits on $\mathrm{E}$ coast of Mon Bay W Spitzbergen. Coll 1966 and subm by L Troitski.

Tln-48. Mleles Sala

$\geqslant 45,500$

Plant remains underlying gravel and aleurite, at depth 185 to $190 \mathrm{~cm}$, from right bank of Niemen $R$ in Druskininkai, Lithuanian SSR. Coll 1972 by J M Punning, R Rajamäe, and L Smirnova, Inst Geol.

\section{Koleshki series}

Profile Koleshki is ca $1 \mathrm{~km}$ downstream from v Koleshki on Vaga $\mathrm{R}$ (tributary of Severnaya Dvina R), Arkhangelsk Dist, Russian SFSR. Two complexes of interstage sediments are in profile in sands at depth 1300 to $1320 \mathrm{~cm}$ with many shells, and underlain by 2 thin layers of peat, at depth 1530 to $1550 \mathrm{~cm}$. Average alt of exposure from river level is ca $19 \mathrm{~m}$. Samples coll 1972 by J M Punning.

Tln-52. Koleshki-1

$31,900 \pm 800$

Shells at depth 1300 to $1320 \mathrm{~cm}$. 
TIn-49. Koleshki-1

Reed peat at depth 1535 to $1537 \mathrm{~cm}$.

Tln-71. Koleshki-1

Sedge peat at depth 1547 to $1550 \mathrm{~cm}$.

Tln-63. Koleshki-2

Peat from profile $300 \mathrm{~m}$ 71) Peat, $40 \mathrm{~cm}$ thick, . level. Coll from upper part of complex 1972 by J M Punning.

\section{Tln-50. Krasnaya Gorka}

$38,300 \pm 1400$ $36,350 \mathrm{BC}$

Sedge peat from exposure near Rogatchov, on right bank of Dnieper $\mathrm{R}$, Byelorussian SSR. Ancient sediments, $30 \mathrm{~cm}$ thick, lie in complex of sand at depth $600 \mathrm{~cm}$. Comment: dated at Leningrad State Univ ${ }^{14} \mathrm{C}$ lab at 30,000 to 46,000 (Voznyaczyk Arslanov, 1971). Coll 1972 by J M Punning, R Rajamäe, and L Smirnova.

Tln-51. Chornyi Bereg

$\geqslant 46,000$

Buried peat from till exposure near Surazh on right bank of Zapadnaya Dvina R, Byelorussian SSR. Coll 1972 by J M Punning, R Rajamäe, and L Smirnova.

\section{Malaya Khadata series}

Tln-56. Malaya Khadata

$5680 \pm 120$ 3730 BC

Peat, underlying loam at depth 45 to $50 \mathrm{~cm}$ from knoll on valley bog of Malaya Khadata R, $2 \mathrm{~km}$ S of Malaya Khadata Lake. Average thickness of peat is $160 \mathrm{~cm}$. Coll 1972 and subm by L Troitski.

TIn-64. Malaya Khadata

$6315 \pm 70$

Peat from depth 95 to $100 \mathrm{~cm}$.

4365 BC

Tln-53. Malaya Khadata

$5590 \pm 50$

3640 BC

Peat from depth 155 to $160 \mathrm{~cm}$. Comment: sample of earlier date than Tln-64 from upper layer.

\section{Tln-86. Malaya Khadata}

$7960 \pm 100$

Same as Tln-53.

\section{Tln-83. Malaya Khadata-1}

$6010 \mathrm{BC}$

Peat $200 \mathrm{~cm}$ thick, overlying clay loam, from peat knoll on coast of Malaya Khadata Lake, Polar Ural. From depth 40 to $45 \mathrm{~cm}$. Coll 1973 by $\mathrm{L}$ Troitski. 
TIn-84. Malaya Khadata-1

$6745 \pm 70$

Peat from depth 95 to $100 \mathrm{~cm}$.

4795 BC

Tln-85. Malaya Khadata-1

$8670 \pm 100$

Peat from basal layer of complex, at depth 195 to $200 \mathrm{~cm}$.

Tln-57. Yenga

$3480 \pm 60$

$1530 \mathrm{BC}$

Wood remains from exposure by Yenga R, Polar Ural. The ancient sediments consist of loam, gravel with wood remains, and clay. Coll 1972 and subm by $\mathrm{L}$ Troitski.

TIn-58. Silla

$8770 \pm 120$

$6820 \mathrm{BC}$

Decomposed woody peat from excavations Silla, in Karula upland, Estonian SSR. Sample from depth 390 to $400 \mathrm{~cm}$, at a lower contact of organic sediments. Coll 1972 and subm by R Karukäpp, Inst Geol.

\section{Tln-59. Kuigli}

$8865 \pm 70$

Decomposed reed peat from excavations Kuigli in Karula upland, Estonian SSR. Bog sediment in esker hollow is $265 \mathrm{~cm}$ thick. Sample from depth 250 to $265 \mathrm{~cm}$; coll 1972 and subm by R Karukäpp.

TIn-60. Yelovetch

$1270 \pm 70$

Charcoal from cultural layer of settlement Yelovetch on right bank of Onega R, Arkhangelsk Dist. Coll 1971 and subm by E Devyatova, Inst Geol, Karelia Branch Acad Sci USSR.

TIn-62. Kurgesoo

$$
865 \pm 80
$$

AD 1085

Reed peat from lagoon sediments at depth 140 to $150 \mathrm{~cm}$ on Isle Hiiumaa, Estonian SSR. Sample coll 1971 by H Kessel and U Sepp, Inst Geol. Comment: date shows change from lagoon into marshland.

Tln-65. Palivere

$8640 \pm 70$

$6690 \mathrm{BC}$

Wood peat from under beach barrier of Ancylus Lake, near Palivere RR Sta, Haapsalu Dist, Estonian SSR. Pollen analyses by H Kessel refer the peat to Pollen Zone BO 2. Coll 1972 and subm by U Paap, Inst Geol.

\section{Tln-66. Kôdu}

$8480 \pm 90$

Wood peat from under beach barrier of Ancylus Lake, $20 \mathrm{~km}$ NE of Pärnu, Estonian SSR. Sample from upper part of organic sediments, $30 \mathrm{~cm}$ thick. Pollen analyses by $\mathrm{H}$ Kessel refer peat to Pollen Zone $\mathbf{B O}_{2}$. Coll 1971 and subm by H Kessel. 
Tln-67. Pervomayskyi

Sphagnum peat buried by sand and aleurite on left bank of Severnaya Dvina $R$, near settlement Pervomayskyi, Arkhangelsk Dist. Sample from upper part of organic sediments $70 \mathrm{~cm}$ thick. Coll 1972 by J M Punning.

\section{Tln-68. Shapurovo}

$31,550 \pm 350$

Plant remains buried by sandy loam and till from right bank of Kasplya R, near settlement Shapurovo, Vitebsk Dist, Byelorussian SSR. Coll 1972 by J M Punning, R Rajamäe, and L Smirnova. Comment: ${ }^{14} \mathrm{C}$ dates by Leningrad State Univ ${ }^{14} \mathrm{C}$ Lab are: LU-78A: 29,150 \pm 850 and LU-78B: $36,400 \pm 800$ (Voznyaczyk, 1972).

\section{Tln-69. Snaigupele}

$42,600 \pm 600$

Submorainic organic deposits from right bank of Snaigupele $R$ (tributary of Niemen R), ca $2 \mathrm{~km}$ from Druskininkai, Lithuanian SSR. Coll 1972 by J M Punning, R Rajamäe, and L Smirnova. Comment: according to Kondratiene (1973) interglacial organic deposits are older than Merkine (Riss-Wurm) and younger than Butenai (Mindel-Riss).

\section{Tln-70. Konopki Lesne}

$39,530 \pm 450$

Interglacial peat from profile Konopki Lesne near Lomza in NE Poland. The profile is outside the reach of the youngest glaciation and peat is covered with sands only. Sample from depth 315 to $345 \mathrm{~cm}$; coll and subm 1971 by E J Mojski, Inst Geol, Warsaw. Comment (BorowkoDlužakowa, 1973; Borowko-Dlužakowa, Halicki, 1957): profile indicates the bipartition of the Eemian Interglacial.

TIn-72. Lomza

Interglacial peat from profile near Lomza in NE Poland (depth 730 to $760 \mathrm{~cm}$ ). Coll and subm 1971 by $\mathrm{E} \mathrm{J}$ Mojski.

\section{Tln-73. Yanonis}

$37,900 \pm 300$

\section{5,950 вс}

Travertine overlain by morainic loam, humified sands with plant remains $(250 \mathrm{~cm})$ near settlement Yanonis, NE of Lithuanian SSR. Sample from upper part of layer; coll 1972 by J M Punning, R Rajamäe, and L Smirnova. Comment: dates from travertine upper stratum: Vs-39: $22,700 \pm 360$; middle: Vs-40: $24,800 \pm 450$, and lower: Vs-41: 27,200 \pm 400 (Vaitonis et al, 1972).

\section{Tln-74. Gaylyunay}

Submorainic complex from left bank of Niemen R, near Druskininkai, Lithuanian SSR. Interglacial (Interstadial) complex consists of aleurite with fragments of shells, and wood remains. Average thickness is $200 \mathrm{~cm}$. Coll 1971 by J M Punning, R Rajamäe, and L Smirnova. 


\section{Tln-75. Kerkidon}

Charcoal and plant remains in flood-plain sediments, at depth $850 \mathrm{~cm}$, from 2nd terrace of right bank Kerkidon R, SE Fergana Valley. Coll 1972 and subm by G Pšenin and L Serebryannyi, Inst Geog.

\section{Tln-76. Kerkidon}

$$
\begin{aligned}
& 6665 \pm 115 \\
& 4715 \mathrm{BC}
\end{aligned}
$$

Charcoal and plant remains at depth $700 \mathrm{~cm}$ from profile Kerkidon (see Tln-75). Coll 1972 and subm by G Pšenin and L Serebryannyi.

\section{TIn-77. Raibola}

Wood peat from left bank of Vaga $\mathrm{R}$ (tributary of Severnaya Dvina R), Arkhangelsk Dist, Russian SFSR. Peat layer is embedded in sands at $500 \mathrm{~cm}$ above river level, and is covered by till. Coll 1972 and subm by E Devyatova.

\section{Tln-78. Sopka}

$8245 \pm 80$

Moss peat from left bank of Severnáya Dvina R, Arkhangelsk Dist, Russian SFSR. Peat lies in river sediments. Coll 1972 by J M Punning.

\section{Sista-Palkino series}

Profile is on right bank of Sista R, $300 \mathrm{~m}$ upstream from hwy bridge in Leningrad Dist, Russian SFSR. Coll 1973 by T Kakum, J M Punning, and R Rajamäe.

\section{TIn-79. Sista-Palkino}

$6000 \pm 80$

Wood peat at depth 270 to $275 \mathrm{~cm}$, embedded during later transgression of Littorina Sea. Pollen analyses by $\mathrm{H}$ Kessel refers deposits to Pollen Zone V.

\section{TIn-80. Sista-Palkino}

$6570 \pm 80$

Wood peat at depth 285 to $290 \mathrm{~cm}$.

$$
4620 \mathrm{BC}
$$

\section{TIn-81. Sista-Palkino}

$7980 \pm 90$

$6030 \mathrm{BC}$

Wood peat at depth 320 to $325 \mathrm{~cm}$. Pollen analyses by H Kessel refers deposits to Pollen Zone VII.

\section{TIn-82. Chartakchay}

$3995 \pm 70$

2045 BC

Peat from 2nd terrace left bank of Chartakchay R, 20km NE of Namangan. Peat underlies gravel in clay complex. Coll 1972 and subm by $G$ Pšenin. 
REFERENCES

Borowko-Dluzakowa, Z, 1973, New localities with Eemian flora in the Polish Lowland: Palynology of pleistocene and pliocene, 3rd internatl palynol conf, Proc Moscow, p 17-20.

Borowko-Dluzakowa, Z, and Halicki, B, 1957, Interglacial sections of the Suwalki region and of the adjacent territory: Acta Geol Polonica, v 7, no. 4, p 361-401 (in Polish).

Kondratiene, O P, 1973, On the types of pollen diagrams of deposits of Merkine (Mikulino, Riss-Würm) interglacial of Lithuania and the problem of their synchronity: Palynology of pleistocene and pliocene, 3rd internatl polynol conf Proc, Moscow, p 44-48 (in Russian).

Punning, J M, Kakum, T, and Rajamäe, R, 1973, Tallinn radiocarbon dates I: Radiocarbon, v 15, p 586-591.

Vaitonis, A, Klimašauskas, A, Kudaba, C, and Sulija K, 1972, About lateantropogen submorainic deposits at village Janonis Lithuanian SSR: Lietuvos TSR Aukštuju Mokyklu Mokslo Darbai, Geog ir Geol, v 9, p 147-150 (in Russian).

Voznyachuk, L, 1972, Age of the maximal stage in the Valdai glaciation at the northwestern part of the USSR and the main phases of glacier's degradation: Problems of Quaternary geol, Riga, v 6, p 29-43 (in Russian).

Voznyachuk, L N and Arslanov, Kh A, 1971, On the paleogeography and geochronology of Valday glaciation in Byelorussia: Chronology of the glacial age: Papers, symposium, Leningrad, p 73-77 (in Russian). 